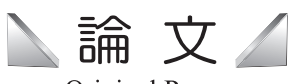

Original Paper

\section{細粒分を含む模擬メタンハイドレート含有砂質堆積物の 三軸圧縮特性とメタンハイドレート分解時の力学挙動 *}

\title{
Triaxial Compressive Properties of Artificial Methane-Hydrate-Bearing Sediments Containing Fine Fraction
}

\author{
by Kuniyuki MIYAZAKI ${ }^{\mathrm{a}}$, Yasuhide SAKAMOTO ${ }^{\mathrm{a}}$, Masayo KAKUMOTO ${ }^{\mathrm{a}}$, Norio TENMA ${ }^{\mathrm{a}}$, \\ Kazuo AOKI ${ }^{\mathrm{a}}$ and Tsutomu YAMAGUCHI ${ }^{\mathrm{b}}$
}

a. National Institute of Advanced Industrial Science and Technology (AIST), 16-1 Onogawa, Tsukuba-shi, Ibaraki, 305-8569, Japan

(*Corresponding author E-mail: sakamoto-yasuhide@aist.go.jp)

b. Department of Environmental Science, Toho University, 2-2-1 Miyama, Funabashi-shi, Chiba, 274-8510, Japan

In this study, drained triaxial compression tests were conducted on artificial methane-hydrate-bearing sediments containing fine fraction. Toyoura sand (average particle size: $D_{50}=0.230 \mathrm{~mm}$, fine fraction content: $\left.F_{\mathrm{c}}=0 \%\right)$, No.7 silica sand $\left(D_{50}=0.205 \mathrm{~mm}, F_{\mathrm{c}}=1.1 \%\right)$ and No.8 silica sand $\left(D_{50}=0.130 \mathrm{~mm}, F_{\mathrm{c}}=11.5 \%\right)$ were used as the skeleton of each specimens. Axial loading was conducted at an axial strain rate of $0.1 \% / \mathrm{min}$ at a constant temperature of $278 \mathrm{~K}$. The cell pressure and pore pressure were kept constant during axial loading. We found that the strength of the hydrate-sand specimens is almost independent of the type of sand forming the skeleton of the specimen. On the other hand, the stiffness of the specimens containing finer sand particles is lower, probably because fine sand particles can more easily penetrate between the sand and hydrate particles, resulting in larger axial deformation. During the dilatant behavior, the lateral expansive displacement of specimens containing finer sand particles is smaller because the compaction process may continue to occur even when the dilatant behavior becomes the dominant mechanism. The formula expressing the secant Young's modulus obtained from the triaxial compression tests was constructed as a function of methane hydrate saturation and effective confining pressure and was introduced to a numerical simulator. The compressive displacement observed in the earlier work concerning the laboratory-scale experiments of methane hydrate dissociation was simulated by the numerical simulator.

KEY WORDS: Methane Hydrate, Triaxial Compression Test, Strength, Elastic Modulus, Fine Fraction, Depressurization Method

\section{1. は じめに}

我が国周辺の海底堆積層において, 天然のメタンハイドレート (Methane Hydrate, 以下, MH) が存在することが確認されている ${ }^{1-5)}$ 。 MH は, 水分子により形成されたケージ (カゴ状構造) の中にメ

*2010年 11 月 26 日受付 2011 年 6 月 20 日受理

1. 正会員工博 (独) 産業技術総合研究所メタンハイドレート研究センター 研究員

2. 正会員 工博 (独) 産業技術総合研究所地圈資源環境研究部門 研究員

3. (独) 産業技術総合研究所メタンハイドレート研究センターテクニカル スタッフ

4. 正会員工博 (独) 産業技術総合研究所メタンハイドレート研究センター

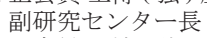

5. 正会員工博 (独) 産業技術総合研究所メタンハイドレート研究センター 招聘研究員

6. 正会員 工博 東邦大学 理学部 生命圈環境科学科教授

[ 著者連絡先 ] FAX: 029-861-3101 E-mail: miyazaki-kuniyuki@aist.go.jp

キーワード : メタンハイドレート，三軸圧縮試験，強度，変形係数，細粒 分, 減圧法
タン分子を包蔵した固体結晶であり, メタンと水が存在し, 主と して温度と圧力により規定される安定条件下において存在する。 $\mathrm{MH}$ は, 温度や圧力が変化し, 不安定条件下に置かれると, メ夕 ンと水に分解する。海底下に存在する天然の MH を, 何らかの 手法により原位置において分解し, メタンを回収することにより， 新しいエネルギー資源として利用することが期待されている。

海底下に存在する天然の $\mathrm{MH}$ を開発する際, 海底地盤の変形 挙動を予測することは最も重要な課題のひとつである。例えば, 海底地盤の変形によって, 周辺の海洋環境が変化する可能性があ る。また, $\mathrm{MH}$ の胚胎する堆積層 ( 以下, $\mathrm{MH}$ 層) の変形により, その浸透率特性が変化し, MH の生産性に影響をおよぼす可能性 が指摘されている ${ }^{6,7)}$ 。従って, 天然の MH を安全かつ経済的に 生産するためには, 生産時における $\mathrm{MH}$ 層の力学挙動を予測す る手法を確立することが必要不可欠である。

MH 層の力学挙動を予測するには, MH 層の力学特性を把握し ておかなければならない。天然の MH は, 砂質堆積層中の孔隙 


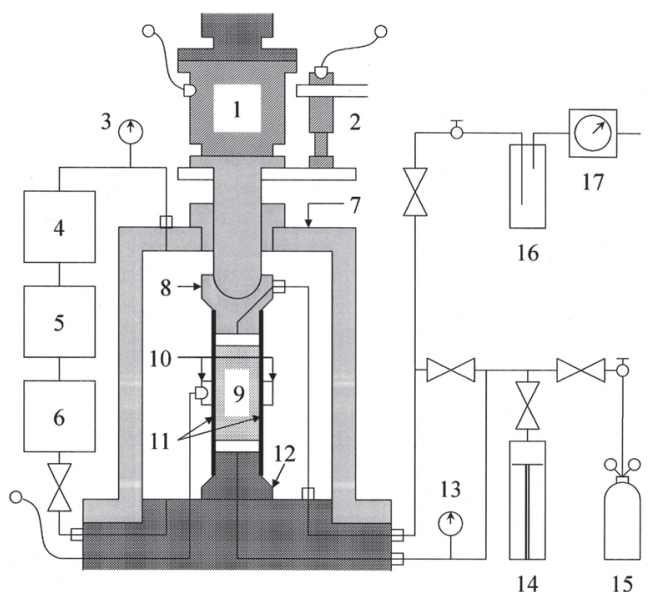

1. Load cell 10. Lateral displacement transducer 2. Axial displacement transducer 11. Rubber membrane

3. Cell pressure gauge

4. Cell pressure controller

5. Refrigerant cooling tank

6. High-pressure pump

7. Triaxial cell

8. Top cap

9. Specimen

Fig.1 Schematic illustration of the apparatus for triaxial compression test

内に胚胎していることが多い。その意味では，MH と砂との混合 物の力学特性 ${ }^{8-18)}$ が実用上重要といえる。例えば, 著者ら 14,15 , 17, 18) は, MH を含有する模擬砂質堆積物を対象として, 排水三 軸圧縮応力下における力学特性を実験的に取得し, その力学特性 についてある程度明らかにしてきた。しかし, これら一連の研究 では, 模擬砂質堆積物の骨格を成す砂として, 細粒分 ( 粒径 0.075 $\mathrm{mm}$ 未満の土粒子) を含まない豊浦砂を用いた試験結果しか示さ れていない。天然の $\mathrm{MH}$ が存在する我が国周辺の海底堆積層に

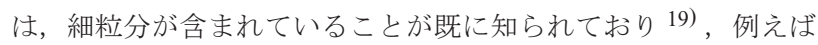
豊浦砂と比較すると, ほとんどの場合, 平均粒径は小さいもの と推定される。従って, 比較的粒径の小さな土粒子により骨格 を形成された $\mathrm{MH}$ 層の力学特性を取得しておくことは, フィー ルドにおける $\mathrm{MH}$ 層の力学挙動を予測する上で必要不可欠であ ろう。細粒分を含む天然 MH 層コアの力学特性に関しては, こ れまでいくつかの実験的研究が行われている。Winters et al. ${ }^{8,9)}$ は, Mackenzie Delta や Krishna-Godavari Basinより取得された天 然 MH 層の供試体を用いて非排水三軸圧縮試験を行い，三軸圧 縮強度, 弾性波速度, 透水係数などの物理的特性が, 供試体が $\mathrm{MH}$ を含むか否かによって大きく異なること, 天然 MH 層コアの 保存温度の影響を受けること, また, 試料の骨格を成す砂の粒径 が小さいほどその影響が大きいこと，などを示した。しかし，人 工的に作製した MH 含有砂質堆積物との比較はなされていない。 Masui et al. ${ }^{12)}$ は，基礎試錐「東海沖〜熊野灘」にて取得された天 然 $\mathrm{MH}$ 層コアの供試体を用いて排水三軸圧縮試験を行い, 人工 的に作製した MH 含有砂質堆積物との比較を行っている。しか し, Masui et al. ${ }^{12)}$ が比較の対象とした模擬 MH 含有砂質堆積物は, その骨格が細粒分を含まない豊浦砂により形成されたものであ り, 細粒分を含む模擬 MH 含有砂質堆積物との 比較は行われていない。

本報では, 細粒分を 含む $\mathrm{MH}$ 層の力学特性 を室内試験により把握 することを目的とする。
模擬砂質堆積物の骨格を成す砂として, 細粒分を含み, 豊浦砂よ りも平均粒径の小さい 7 号珪砂および 8 号珪砂を使用することと した。これらの砂を用いて作製した MH 含有砂に対し，排水三 軸圧縮試験を行い，豊浦砂を用いた既報 18) の結果との比較を通 じて, 細粒分が MH 含有砂の力学特性におよぼす影響を調べた。 また, Masui et al. ${ }^{12)}$ による天然 MH 層コアサンプルの力学特性と の比較も行った。さらに, 本報で得られた試験結果のうち, MH 層の変形と関連の深い変形係数を, MH 飽和率および有効拘束圧 の関数として定式化した後, これを数值シミュレータに組み込み, 数值シミュレーションによって, 坂本らの模擬 MH 層の減圧分 解試験 ( 圧密・浸透連成試験 $)^{7,20)}$ の再現を試みた。

\section{2. 三軸圧縮試験方法}

\section{$2 \cdot 1$ 試験装置}

天然の MH 層から採取したコアサンプルは，稀少である上， MH が常温常圧下では不安定であることから, 力学試験に供する のは技術的に難しい。そのため, MH を含む砂試料を実験室で作 製し，力学試験に用いることが多い 10-18)。Masui et al. ${ }^{11)}$ は，三 軸セル内において, ガス浸透法により模擬砂質堆積物の間隙中に MH を生成し，この供試体に対して三軸圧縮試験を行う手法を開 発した。本報では，この三軸圧縮試験方法に倣うこととした。

Fig. 1 は, 本報の三軸圧縮試験に用いた試験装置の概略図であ る。試験装置の最大軸荷重は $200 \mathrm{kN}$ である。セル液としては濃度 $50 \%$ のエチレングリコール水溶液を使用した。セル液は, 恒温水 槽 (Fig. 1 の) から高圧ポンプ (Fig. 1 の 6) に供給された後, 三軸 セル (Fig. 1 の7) 内に吐出され, セル液の圧力 (以下, セル圧) を 調節するシリンダ (Fig. 1の 4) を通して恒温水槽に戻る。このセル 液循環システムにより, 試験中の供試体温度を $243 \sim 293 \mathrm{~K}(-30$ 〜 $\left.+20{ }^{\circ} \mathrm{C}\right)$ の範囲でほぼ一定 $( \pm 0.5 \mathrm{~K})$ に保つことができ, かつ, 供試体に対して最大 $20 \mathrm{MPa}$ の拘束圧を負荷させることができる。

\section{$2 \cdot 2$ 砂質堆積物試料}

MH を含む模擬砂質堆積物 ( 以下, MH 含有砂供試体, hydratesand specimen）を作製するために，まず，砂と水のみを用い，そ の骨格となる堆積物試料を作製する必要がある。作製方法は以下 の通りである。まず, 内径 $50 \mathrm{~mm}$, 高さ $100 \mathrm{~mm}$ の型枠に振動を 与えながら, 水中落下により砂を密詰めにした。型枠を飽和砂で 充填した後, ハンドポンプによる排水を行い, 水飽和度が 40 $70 \%$ の範囲内の所定の值となるように含水量を調整した。この ときの含水量により，供試体内部における MH の生成量がおお よそ決定される。その後, 不飽和状態の砂試料をキャッピングし, $258 \mathrm{~K}\left(-15^{\circ} \mathrm{C}\right)$ の冷凍庫内にて 12 時間以上保存して凍結させた。

本報では， 7 号珪砂および 8 号珪砂を使用した。Table 1 に, 既報 18) で使用した豊浦砂と， 7 号珪砂および 8 号珪砂の諸元を 示す。また, Fig. 2 には, 豊浦砂, 7 号珪砂, 8 号珪砂の粒度分 布を示す。これらの砂の主成分はいずれもシリカ $\left(\mathrm{SiO}_{2}\right)$ である。 Table 1 や Fig. 2 からわかるように, 細粒分含有率は, 豊浦砂, 7 号珪砂, 8 号珪砂の順に低く, 平均粒径はこの順に大きい。Table 1 には, 凍結した堆積物試料の体積および作製時に使用した砂の 重量などから算出した孔隙率, 乾燥密度, 相対密度の各平均值も

Table 1 Specifications of types of sand and host specimens

\begin{tabular}{llllllll}
\hline Sand & $\begin{array}{l}\text { Soil particle } \\
\text { density, } \mathrm{g} / \mathrm{cm}^{3}\end{array}$ & $\begin{array}{l}\text { Fine fraction } \\
\text { content, } \%\end{array}$ & $\begin{array}{l}\text { Mean particle } \\
\text { size, } 10^{-6} \mathrm{~m}\end{array}$ & $\begin{array}{l}\text { Uniformity } \\
\text { coefficient }\end{array}$ & Porosity, \% & $\begin{array}{l}\text { Dry density, } \\
\mathrm{g} / \mathrm{cm}^{3}\end{array}$ & $\begin{array}{l}\text { Relative } \\
\text { density }\end{array}$ \\
\hline Toyoura sand & 2.63 & 0.0 & 230 & 1.38 & 37.8 & 1.64 & 0.96 \\
\hline No.7 silica sand & 2.59 & 1.1 & 205 & 1.58 & 38.6 & 1.59 & 0.96 \\
\hline No.8 silica sand & 2.59 & 11.5 & 130 & 2.00 & 41.2 & 1.52 & $(1.00)$ \\
\hline
\end{tabular}




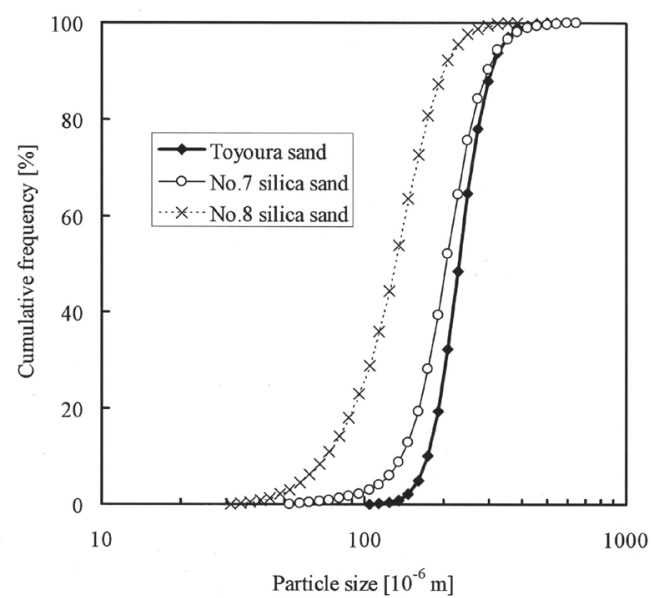

Fig.2 Cumulative frequency curves of particle size for the types of sand used.

示した。相対密度は, 乾燥密度と最小密度・最大密度試験 (JIS A 1224:2009)の結果から算出した。ただし，JIS A 1224:2009では, その適用範囲を原則として細粒分含有率 $5 \%$ 以下の砂に限定して いる。8 号珪砂の場合はこの範囲から外れているため, 表に示し た相対密度は参考值と考え, 括弧付きで示した。表からわかるよ うに, 全ての砂で相対密度は 0.95 以上であり, 試験に供した堆 積物試料の砂は十分密に詰められていると考えられる。

\section{$2 \cdot 3 \mathrm{MH}$ の生成過程と残留メタンの水置換過程}

$\mathrm{MH}$ の生成と残留メタンガスの水置換は以下の手順に従って 行った。まず，凍結した砂試料をゴムスリーブ（Fig. 1 の 11）で被 覆し, キャップ (Fig. 1の 8) およびペデスタル (Fig. 1の 12) とと もに, 試験装置の中央部分に設置した。このとき, 供試体中央 部における横方向 (直径方向) の変位を測定するため, 差動卜ラ ンスを組み込んだ測定治具 (Fig. 1 の 10) を取付けた。Fig. 3 はこ のときの様子である。その後, 三軸セルを設置し, セル液の循 環によって砂試料温度を氷点下に保つとともに, メタンガスボ ンベ (Fig. 1の 15) より供給されるメタンガスを砂試料の下端より 浸透させ，間隙内の空気を置換した。続いて, Fig. 1 のおよび 13 により測定されるセル圧および間隙ガス圧を $0.5 \sim 0.7 \mathrm{MPa} /$ $\min$ の速さで同時に昇圧し, 間隙ガス圧は $8 \mathrm{MPa}$ に, セル圧は 8.5 $\mathrm{MPa}, 9 \mathrm{MPa}, 11 \mathrm{MPa}$ のいずれかにした。これと並行して, セル 液の温度を上昇させることで, 三軸セル内および砂試料の温度を $278 \mathrm{~K}\left(5{ }^{\circ} \mathrm{C}\right)$ で一定にした。これらの温度・圧力条件は, 海底堆 積層に存在する天然 $\mathrm{MH}$ 層の環境から設定した。その後, 間隙 ガス圧, セル圧, 砂試料温度を一定に保ち, 砂試料中の間隙内に MH を生成させた。MH の生成後, 試料下端から水を浸透させ, 間隙内に残留するメタンガスを水で置換した。水置換中の間隙圧, セル圧および試料温度は, MH の生成 過程から継続してほぼ一定に保った。 このようにして，三軸セル内にて，凍 結した砂試料から MH 含有砂供試体を 作製した。

本報では，比較のため, $\mathrm{MH}$ を生成 させずに砂試料を水で飽和した供試体 ( 以下, 飽和砂供試体, water-saturated sand specimen) についても試験を行っ た。飽和砂供試体を作製する場合に は, 凍結した砂試料を試験装置に設置 した後, 冷媒圧力を $0.5 \mathrm{MPa}, 1 \mathrm{MPa}$,

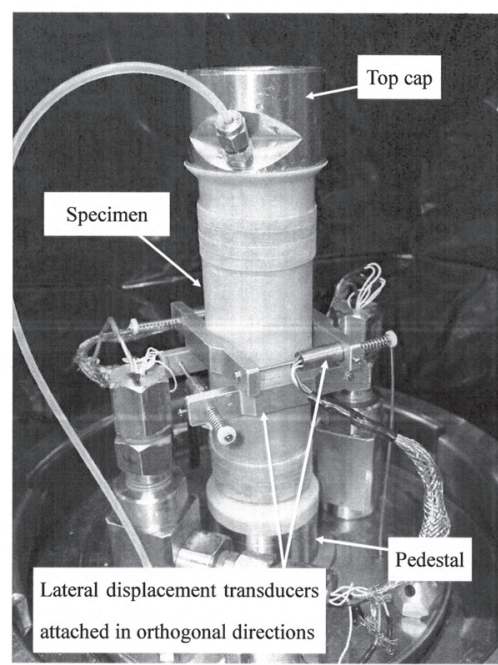

Fig.3 Setup of frozen host specimen.

$3 \mathrm{MPa}$ のいずれか, 砂試料温度を $278 \mathrm{~K}\left(5{ }^{\circ} \mathrm{C}\right)$ として, 水飽和を 行い, その後, セル圧を $8.5 \mathrm{MPa}, 9 \mathrm{MPa}, 11 \mathrm{MPa}$ のいずれかに, 間隙水圧を $8 \mathrm{MPa}$ に，それぞれ昇圧した。

\section{$2 \cdot 4$ 軸載荷過程と MH の分解過程}

残留メタンガスの水置換後, 三軸圧縮応力下における軸載荷を 両端排水条件下にて行った。軸載荷過程中, 間隙圧および温度は, MH の生成過程および残留ガスの水置換過程から継続して一定に 保った。また, 軸荷重はロードセル (Fig. 1の 1) により, 軸変位 量は差動トランス (Fig. 1の2)により測定した。ロードセルは三 軸セル外部に取付けられているため, 軸荷重の測定值は載荷ピス トンと三軸セルとの摩擦を含むことになる。本報で行った試験と 同等のセル圧を負荷した状態でこの摩擦を測定し, 供試体の断面 積で除したところ高々 $0.05 \mathrm{MPa}$ であった。本報では, この摩擦 の影響を無視することとし, 補正を見送った。軸載荷は一定の軸 ひずみ速度 $0.1 \% / \min$ で行った。

軸載荷終了後, 間隙圧を減じて供試体内の $\mathrm{MH}$ を分解させ, メタンガスを回収した。ガス流量計 (Fig. 1 の 17)により測定され る分解メタンガスの総回収量および $\mathrm{MH}$ の密度 $0.913 \mathrm{~g} / \mathrm{cm}^{3}$ を用 いて, 供試体内に存在していた $\mathrm{MH}$ の体積を算出し, これを基 に初期状態における供試体の MH 飽和率, 寸なわち, 供試体の 間隙内に占める MH の体積比率を算出した。

Table 2 に三軸圧縮試験条件を示した。表には, 豊浦砂を使用 した既報 ${ }^{18)}$ での試験条件も示してある。使用した砂, 間隙圧, セル圧が同一の条件下において, それぞれ 3 本の飽和砂供試体 $(\mathrm{MH}$ 飽和率 $0 \%)$ と $\mathrm{MH}$ 飽和率の異なる 4 本から 7 本の $\mathrm{MH}$ 含有 砂供試体に対して, 試験を行った。

Table 2 Conditions of triaxial compression test.

\begin{tabular}{|c|c|c|c|c|}
\hline Sand & $\begin{array}{l}\text { Pore pressure, } \\
\mathrm{MPa}\end{array}$ & $\begin{array}{l}\text { Cell pressure, } \\
\mathrm{MPa}\end{array}$ & $\begin{array}{l}\text { Effective confining } \\
\text { pressure, } \mathrm{MPa}\end{array}$ & Methane hydrate saturation, $\%$ \\
\hline \multirow[t]{4}{*}{ Toyoura sand } & 8 & 8.5 & 0.5 & $0(\times 3), 13,21,28,35,45,49,57$ \\
\hline & & 9 & 1 & $0(\times 3), 15,16,21,34,39,41,48$ \\
\hline & & 10 & 2 & $0(\times 3), 14,22,31,43,49$ \\
\hline & & 11 & 3 & $0(\times 3), 11,17,27,33,42,52$ \\
\hline \multirow[t]{3}{*}{ No.7 silica sand } & 8 & 8.5 & 0.5 & $0(\times 3), 13,25,44,49$ \\
\hline & & 9 & 1 & $0(\times 3), 17,28,33,42,49$ \\
\hline & & 11 & 3 & $0(\times 3), 15,23,43,49$ \\
\hline \multirow[t]{3}{*}{ No. 8 silica sand } & 8 & 8.5 & 0.5 & $0(\times 3), 19,28,41,44$ \\
\hline & & 9 & 1 & $0(\times 3), 19,37,40,42,48$ \\
\hline & & 11 & 3 & $0(\times 3), 23,30,43,50$ \\
\hline
\end{tabular}



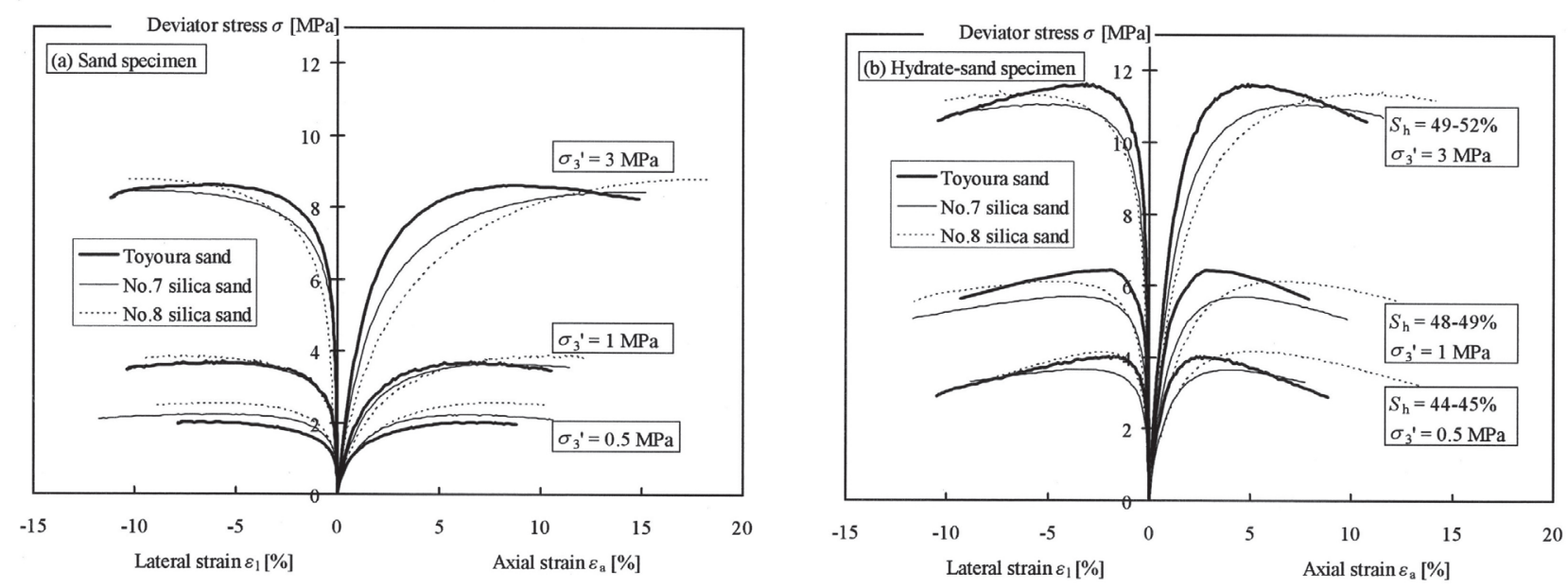

Fig.4 Deviator stress $\sigma$ versus axial strain $\varepsilon_{\mathrm{a}}$ and lateral strain $\varepsilon_{1}$ for (a) water-saturated sand specimens $\left(S_{\mathrm{h}}=0 \%\right)$ and (b) hydrate-sand specimens $\left(S_{\mathrm{h}}=44-52 \%\right)$.
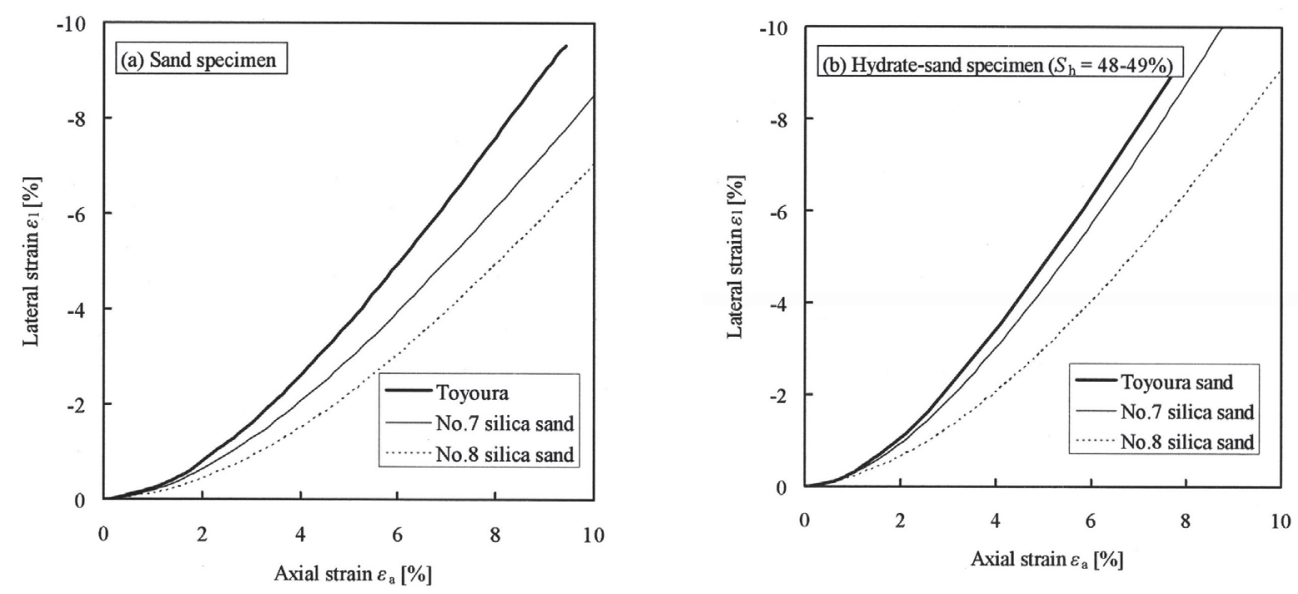

Fig.5 Axial strain $\varepsilon_{\mathrm{a}}$ versus lateral strain $\varepsilon_{1}$ for (a) water-saturated sand specimens $\left(S_{\mathrm{h}}=0 \%\right)$ and (b) hydrate-sand specimens $\left(S_{\mathrm{h}}=48-49 \%\right)$ under $1 \mathrm{MPa}$ effective confining pressure.

\section{3. 三軸圧縮試験結果}

\section{$3 \cdot 1$ 応力とひずみ}

三軸圧縮試験より得られた軸差応力と軸ひずみ，および，軸差 応力と横ひずみとの関係 ( 以下, 応力ーひずみ曲線) を Fig. 4 に 示す。軸ひずみおよび横ひずみは, 差動トランスにより測定した 軸方向変位および横方向変位を, それぞれ軸載荷前の供試体高さ および直径で除して算出したものであり，本報ではいずれも圧縮 を正として表記する。Fig. 4 (a) および (b) はそれぞれ飽和砂供試 体および MH 含有砂供試体の結果である。図中に示した $\sigma_{3}{ }^{\prime}$ は有 効拘束圧である。

飽和砂供試体の場合, Fig. 4 (a) より, 有効拘束圧や使用した砂 によらず, 最初, 軸ひずみが増加するにつれて軸差応力は増加す るが, 曲線の勾配は徐々に減少していき, やがて横軸とほぼ平行 になることがわかる。また, 使用した砂によらず, 有効拘束圧が 大きいほど, 軸差応力の最大值 (以下, 強度) や載荷初期の曲線 の傾きが大きい傾向が見られる。次に, MH 含有砂供試体の場合, 応力ーひずみ関係は, MH 飽和率に依存することが既に知られて いる 10,11) ため, Fig. 4 (b) には, 各有効拘束圧において MH 飽和 率の近い試験より得られた結果を選択して示した。Fig. 4 (b) より, MH 含有砂供試体の場合も, 有効拘束圧の影響に関しては, 飽和 砂供試体と同様の傾向が見られる。また, 有効拘束圧が大きいほ
ど, 軸差応力がピークとなるときの軸ひずみが大きいことがわか る。軸差応力と横ひずみとの関係については, 軸差応力と軸ひず みとの関係と, 定性的には類似している。以上のことは, 豊浦砂 を使用した場合に関しては, 既に公表した結果であり ${ }^{18)}$, 本報 の結果から 7 号珪砂や 8 号珪砂を使用した場合にも, 同様のこと がいえることが明らかとなった。砂による応力ーひずみ曲線の違 いについては, 飽和砂供試体, MH 含有砂供試体のいずれの場合 でも, 応力がピークとなるときの軸ひずみが, 8 号珪砂, 7 号珪砂, 豊浦砂の順に大きいことがわかる。

有効拘束圧 $1 \mathrm{MPa}$ の試験で得られた横ひずみと軸ひずみとの 関係を Fig. 5 に示す。飽和砂供試体, MH 含有砂供試体のいずれ の場合でも, 同じ軸ひずみにおける横ひずみの絶対值は，8号珪 砂, 7 号珪砂, 豊浦砂の順に小さいことがわかる。

Fig. 4 および Fig. 5 から, 8 号珪砂, 7 号珪砂, 豊浦砂の順に, 軸方向の変形が大きく, 横方向への変形は相対的に小さいことが わかる。既報 15,17$)$ では, MH 含有砂供試体の載荷初期における 主たる変形機構は, 固体粒子 (土粒子や $\mathrm{MH}$ ) の互いの隙間への貫 入であり, その後, 次第にせん断変形に伴う固体粒子相互の移動 と回転が卓越し, ダイラタンシーが生じると考察した。また, ダ イラタンシーの結果として供試体の横方向の変形が生じていると 考察した。これらの考察に基づけば, 上記の結果は次のように解 釈される。本報で使用した砂は, Fig. 2 に示寸粒度分布を有してお 

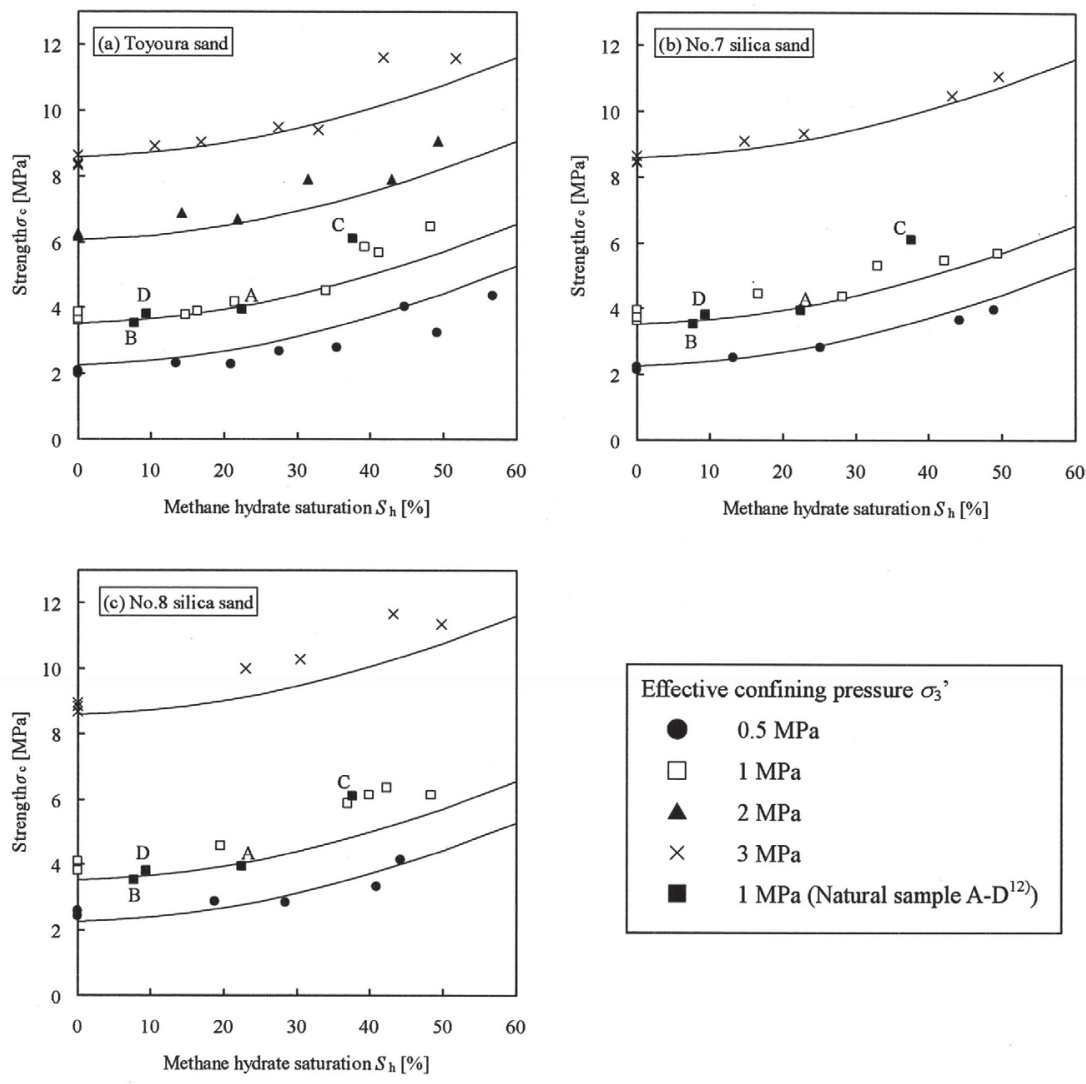

Fig.6 Strength $\sigma_{\mathrm{C}}$ versus methane hydrate saturation $S_{\mathrm{h}}$ for the specimens containing (a) Toyoura sand, (b) No.7 silica sand and (c) No.8 silica sand under effective confining pressures $\sigma_{3}$ ' of $0.5 \mathrm{MPa}, 1 \mathrm{MPa}, 2 \mathrm{MPa}$ and $3 \mathrm{MPa}$. The curves are calculated using Eq. 1 $^{18)}$.

り，供試体中の土粒子の大きさは均一ではない。例えば, Table 1 に示した均等係数 (Uniformity coefficient) からも示唆されるよう に, 粒径分布の範囲は, 8 号珪砂, 7 号珪砂, 豊浦砂の順に広い。 ここで, 供試体中に存在する細粒分などの相対的に小さな粒子は, 相対的に大きな粒子の形成する骨格の隙間へ貫入しやすいため, 粒径分布の範囲が広い砂により骨格が形成された供試体ほど, 載 荷方向の変形が大きい傾向を示したと考えられる。また，そのよ うな供試体では，固体粒子の互いの隙間への貫入の影響が大きい ため, 固体粒子相互の移動と回転の影響が相対的に小さく，その 結果, 横方向への変形が小さい傾向を示したと考えられる。

\section{$3 \cdot 2$ 強度特性と変形特性}

豊浦砂， 7 号珪砂， 8 号珪砂を使用した供試体の強度と MH 飽 和率との関係を，それぞれ Fig. 6 (a)，(b)，(c) に示す。ある程度 のばらつきは見られるものの,いずれの砂を使用した供試体でも, MH 飽和率が大きいほど, 強度が増加する傾向が見られ, MH 飽 和率 $20 \%$ 程度以上ではその傾向が顕著になるようである。また, 通常の地盤材料と同様, 有効拘束圧が大きいほど, 強度は大きい。 既報 ${ }^{18)}$ では, 豊浦砂を使用した供試体の強度に関して, MH 飽 和率と有効拘束圧を考慮した実験式を導出した。

$$
\begin{aligned}
& \sigma_{\mathrm{C}}\left(S_{\mathrm{h}}, \sigma_{3^{\prime}}\right)=\frac{2 \cdot \cos \phi}{1-\sin \phi} c\left(S_{\mathrm{h}}=0\right)+\alpha \cdot S_{\mathrm{h}}{ }^{\beta}+\frac{2 \cdot \sin \phi}{1-\sin \phi} \sigma_{3^{\prime}} \\
& c\left(S_{\mathrm{h}}=0\right)=0.27 \\
& \phi=34.0 \\
& \alpha=1.91 \times 10^{-3} \\
& \beta=1.80
\end{aligned}
$$

ここで, $\sigma_{\mathrm{C}}\left(S_{\mathrm{h}}, \sigma_{3}{ }^{\prime}\right)$ は有効拘束圧 $\sigma_{3}{ }^{\prime}[\mathrm{MPa}]$ における $\mathrm{MH}$ 飽和率 $S_{\mathrm{h}}$ [\%] の供試体の強度 [MPa], $c\left(\mathrm{~S}_{\mathrm{h}}=0\right)$ は飽和砂供試体の粘着力 [MPa], $\phi$ は飽和砂供試体の内部摩擦角 $\left[{ }^{\circ}\right], \alpha[\mathrm{MPa}]$ と $\beta$ は $\mathrm{MH}$ 含有砂供試体の試験結果から最小二乗近似により求めたパラメー タである。Fig. 6 に示した曲線は, 各有効拘束圧において, (1) 式 により計算される強度と MH 飽和率との関係である。Fig. 6 (b) , (c) から，8 号珪砂を使用した場合の有効拘束圧 $1 \mathrm{MPa}$ と $3 \mathrm{MPa}$ での 強度が，(1) 式よりも若干大きいものの， 7 号珪砂と 8 号珪砂を使 用した場合の強度は, 豊浦砂を使用した場合と大きな違いは見ら れないことがわかる。

豊浦砂, 7 号珪砂, 8 号珪砂を使用した供試体の割線変形係数 と MH 飽和率との関係を，それぞれ Fig. 7 (a)，(b)，(c) に示す。 ここで, 割線変形係数とは, 原点と強度の $50 \%$ の点を通る直線 の傾きである。Fig. 6 と比べてばらつきは大きいものの, いずれ の砂を使用した供試体でも, 強度と同様の傾向, 寸なわち, MH 飽和率や有効拘束圧が大きいほど, 割線変形係数が増加する傾向 が見られる。また, MH 飽和率と有効拘束圧が等しい条件で比較 すると, 割線変形係数は 8 号珪砂, 7 号珪砂, 豊浦砂の順に小さい。 これは, 前述したように, 粒径分布の範囲が広い砂により骨格が 形成された供試体では, 細粒分などの相対的に小さな粒子が骨格 の隙間へ貫入しや寸いために, 等しい軸差応力を受けたときの軸 方向の変形が大きくなるためと考えられる。

豊浦砂, 7 号珪砂, 8 号珪砂を使用した供試体の割線ポアソン 比と MH 飽和率との関係を，それぞれ Fig. 8 (a)，(b)，(c)に示す。 ここで, 割線ポアソン比とは, 強度の $50 \%$ の点における横ひず みの絶対值と軸ひずみとの比である。実験結果のばらつきは大き 

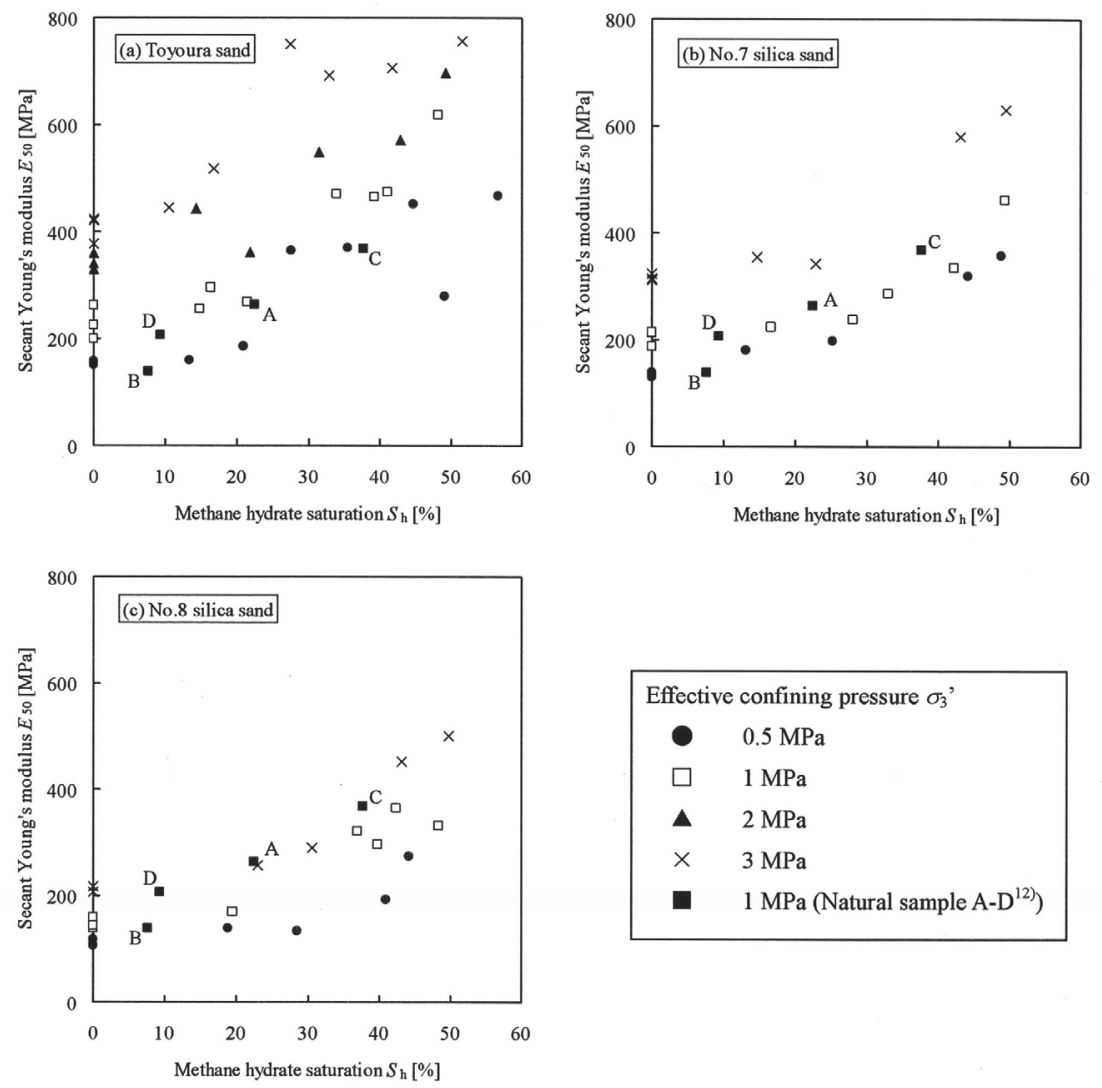

Fig.7 Secant Young's modulus $E_{50}$ versus methane hydrate saturation $S_{\mathrm{h}}$ for the specimens containing (a) Toyoura sand, (b) No.7 silica sand and (c) No.8 silica sand under effective confining pressures $\sigma 3^{\prime}$ of $0.5 \mathrm{MPa}, 1 \mathrm{MPa}, 2 \mathrm{MPa}$ and $3 \mathrm{MPa}$.
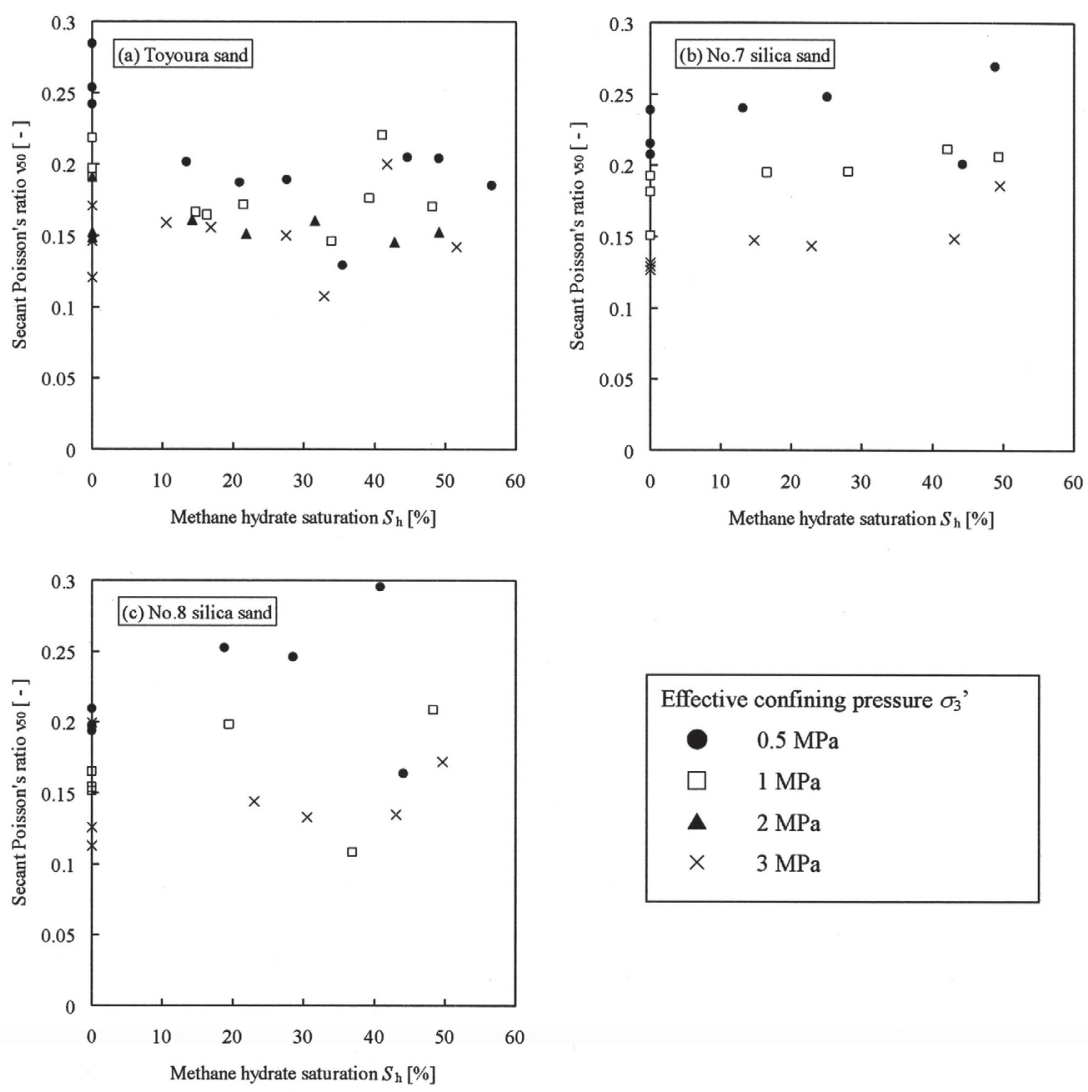

\begin{tabular}{|cc|}
\hline Effective confining pressure $\sigma_{3}^{\prime}$ \\
& $0.5 \mathrm{MPa}$ \\
$\square$ & $1 \mathrm{MPa}$ \\
$\Delta$ & $2 \mathrm{MPa}$ \\
$\times$ & $3 \mathrm{MPa}$ \\
\hline
\end{tabular}

Fig.8 Secant Poisson's ratio $v_{50}$ versus methane hydrate saturation $S_{\mathrm{h}}$ for the specimens containing (a) Toyoura sand, (b) No.7 silica sand and (c) No.8 silica sand under effective confining pressures $\sigma_{3}{ }^{\prime}$ of $0.5 \mathrm{MPa}, 1 \mathrm{MPa}, 2 \mathrm{MPa}$ and $3 \mathrm{MPa}$. 

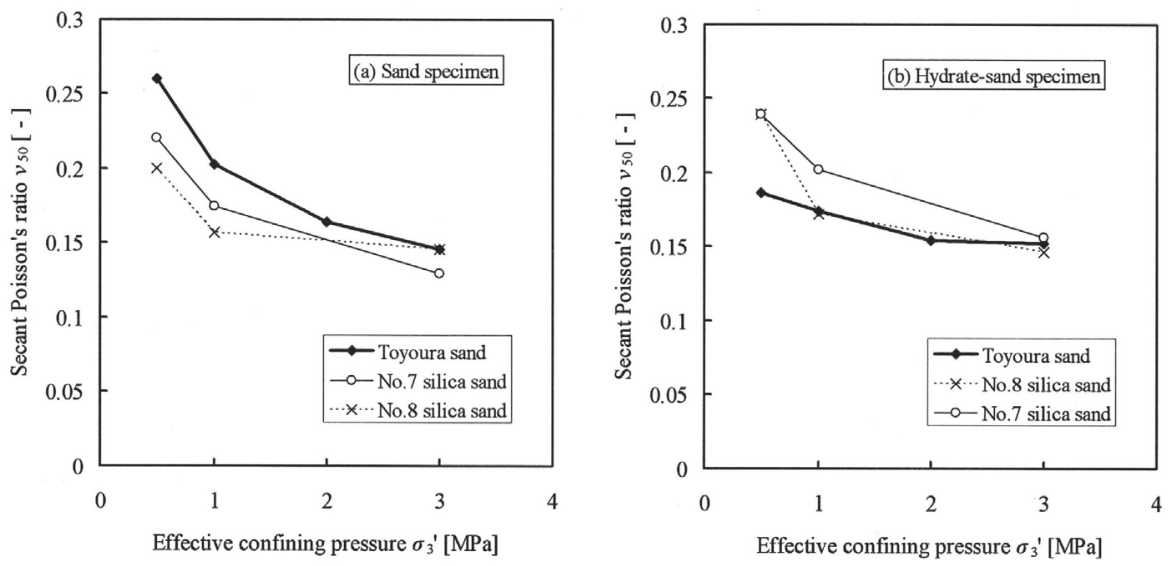

Fig.9 Secant Poisson's ratio $v_{50}$ versus effective confining pressure $\sigma_{3}{ }^{\prime}$ for (a) water-saturated sand specimens and (b) hydrate-sand specimens.

Table 3 Physical properties of natural gas-hydrate-bearing sediment core sample ${ }^{12)}$.

\begin{tabular}{llllllll}
\hline Sample & $\begin{array}{l}\text { Soil particle } \\
\text { density, } \mathrm{g} / \mathrm{cm}^{3}\end{array}$ & $\begin{array}{l}\text { Fine fraction } \\
\text { content, } \%\end{array}$ & $\begin{array}{l}\text { Mean particle } \\
\text { size, } 10^{-6} \mathrm{~m}\end{array}$ & Porosity, $\%$ & $\begin{array}{l}\text { Initial water } \\
\text { content, } \%\end{array}$ & $\begin{array}{l}\text { Bulk density, } \\
\mathrm{g} / \mathrm{cm}^{3}\end{array}$ & $\begin{array}{l}\text { Methane hydrate } \\
\text { saturation, } \%\end{array}$ \\
\hline $\mathrm{A}$ & 2.68 & 42.1 & 84 & 49.0 & 27.9 & 1.75 & 22.5 \\
\hline $\mathrm{B}$ & 2.72 & 17.4 & 140 & 50.8 & 20.4 & 1.72 & 7.7 \\
\hline $\mathrm{C}$ & 2.66 & 11.0 & 160 & 44.2 & 23.0 & 1.83 & 37.6 \\
\hline $\mathrm{D}$ & 2.72 & 9.5 & 180 & 49.3 & 28.7 & 1.77 & 9.4 \\
\hline
\end{tabular}

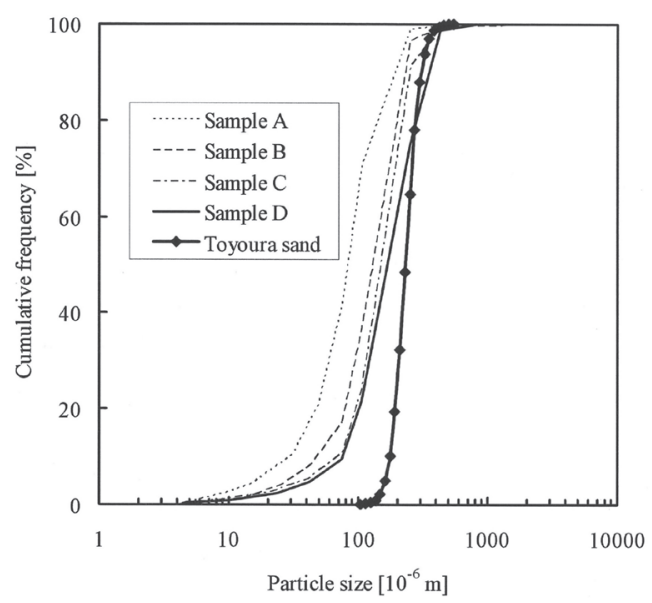

Fig.10 Cumulative frequency curves of particle size for the natural gas-hydratebearing sediment core sample $\mathrm{e}^{12}$.

いものの，ほとんどの場合，割線ポアソン比は 0.1 から 0.3 の間 である。MH 含有砂供試体 $\left(S_{\mathrm{h}}>0 \%\right)$ の割線ポアソン比について は, MH 飽和率の影響は大きくないようである。飽和砂供試体, $\mathrm{MH}$ 含有砂供試体の割線ポアソン比の平均值と有効拘束圧との関 係を，それぞれ Fig. 9 (a)，(b) に示す。飽和砂供試体，MH 含有 砂供試体のいずれの場合でも, また, 豊浦砂, 7 号珪砂, 8 号珪 砂のいずれの砂を用いた場合でも, 有効拘束圧が大きいほど割線 ポアソン比が小さくなる傾向が見られる。

Masui et al. ${ }^{12)}$ による天然 MH 層コアサンプルの力学特性との比 較を行う。Masui et al. ${ }^{12)}$ の用いた 4 本の天然 MH 層コアサンプ ルの物理的性質を Table 3 に, 骨格を成す砂の粒度分布を Fig. 10 に，それぞれ示す。例えば，豊浦砂と比較すると，天然 MH 層 コアサンプルに含まれる砂の粒径は小さいことがわかる。また, その細粒分含有率はサンプルによって異なるが, Sample C と D

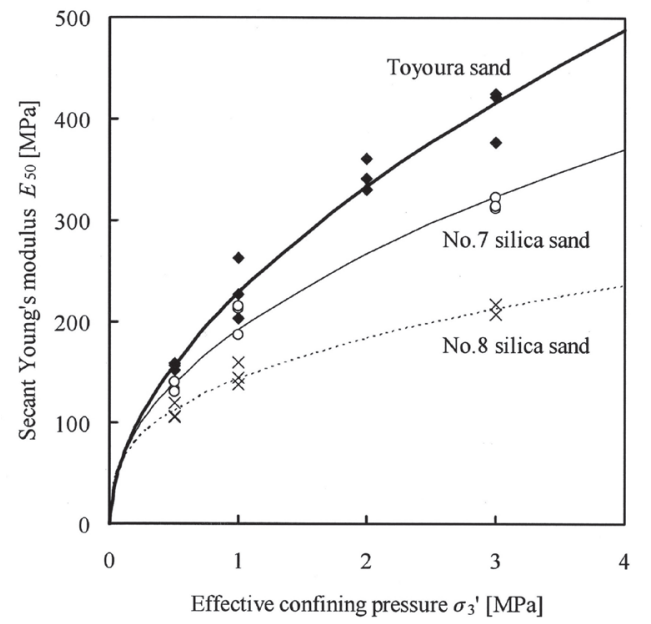

Fig.11 Secant Young's modulus $E_{50}$ versus effective confining pressure $\sigma_{3}$ ' for water-saturated sand specimens containing Toyoura sand, No.7 silica sand and No.8 silica sand. The curves are calculated using Eqs.4-6.

は 8 号珪砂のそれに近く, Sample A と B はそれ以上である。試 験は，有効拘束圧 $1 \mathrm{MPa}$ ，定ひずみ速度 $0.1 \% / \mathrm{min}$ で行われた。 Fig. 6 および Fig. 7 には, Masui et al. ${ }^{12)}$ による天然 MH 層コアサ ンプルの強度および割線変形係数も示した。本報で実験を行った $\mathrm{MH}$ 含有砂供試体と同様, 強度と割線変形係数は MH 飽和率が大 きいほど増加する。Fig. 6 より, 天然 MH 層コアサンプルの強度 は, 本報で用いた MH 含有砂供試体と同程度であることがわかる。 Fig. 7 より, 天然 MH 層コアサンプルの割線変形係数は, 豊浦砂 を使用した MH 含有砂供試体よりも小さく, 比較的, 7 号珪砂や 8 号珪砂を使用した MH 含有砂供試体に近い。天然 MH 層コアサ ンプルの細粒分含有率はいずれも $9.5 \%$ 以上であったため, その 割線変形係数は細粒分を含まない豊浦砂を用いた MH 含有砂供 試体よりも低かったものと考えられる。 

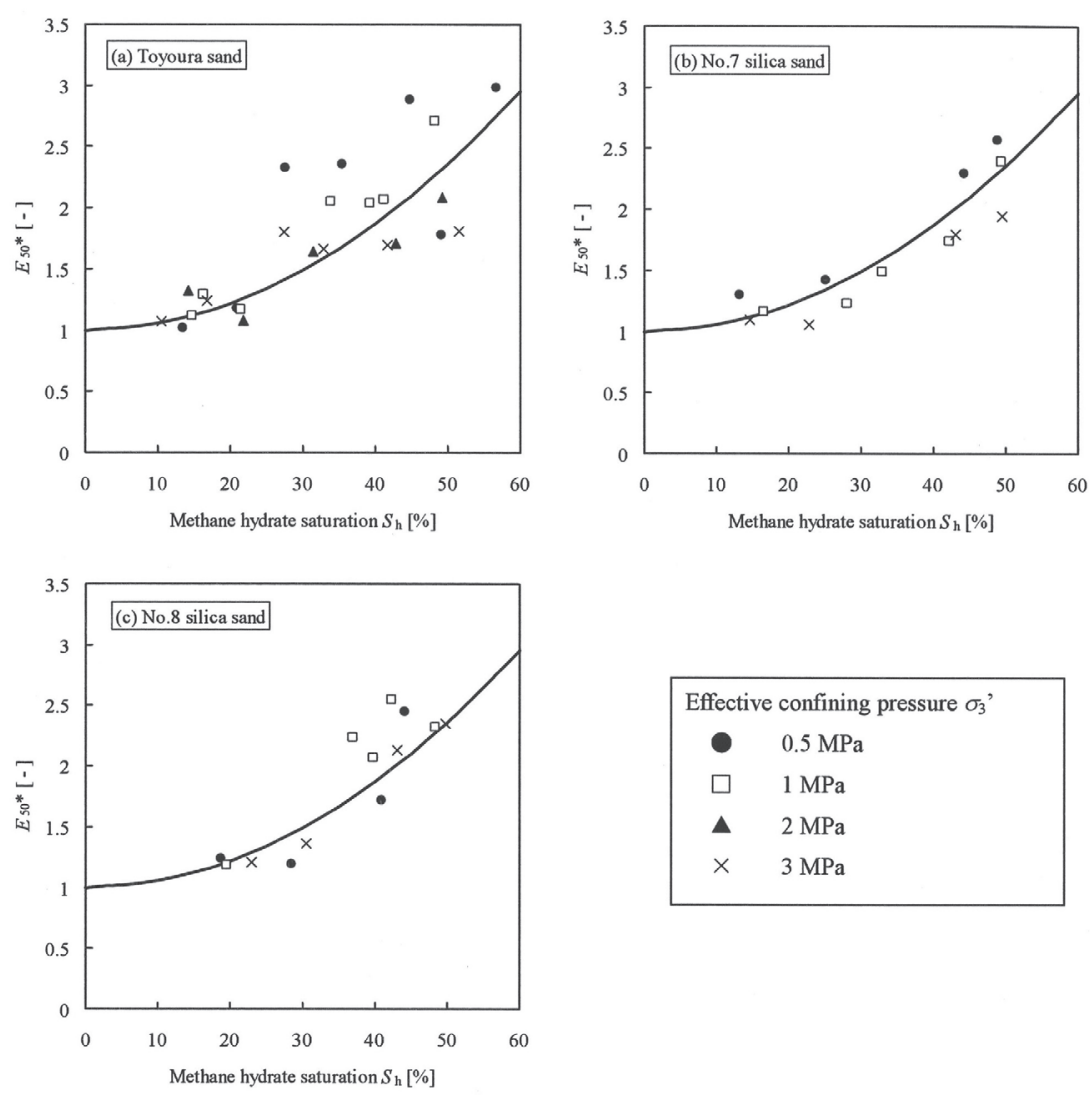

\begin{tabular}{|cl|}
\hline Effective confining pressure $\sigma_{3}{ }^{\prime}$ \\
$\quad$ & $0.5 \mathrm{MPa}$ \\
$\square$ & $1 \mathrm{MPa}$ \\
$\mathbf{A}$ & $2 \mathrm{MPa}$ \\
$\times$ & $3 \mathrm{MPa}$ \\
\hline
\end{tabular}

Fig.12 Normalized secant Young's modulus $E_{50} *$ versus methane hydrate saturation Sh for the specimens containing (a) Toyoura sand, (b) No.7 silica sand and (c) No.8 silica sand under effective confining pressures $\sigma_{3}{ }^{\prime}$ of $0.5 \mathrm{MPa}, 1 \mathrm{MPa}, 2 \mathrm{MPa}$ and $3 \mathrm{MPa}$. The curves are calculated using Eq.8.

\section{$3 \cdot 3$ 変形係数の定式化}

地盤の変形を評価する上で, 変形係数は最も重要な力学パラ メータのひとつである。本節では, 前節で示した割線変形係数 $E_{50}$ を, 有効拘束圧 $\sigma_{3}{ }^{\prime}$ と $\mathrm{MH}$ 飽和率 $S_{\mathrm{h}}$ の関数として, 定式化を 行う。定式化の方法としていくつか考えられるが, 本報では, 手 順の簡単さを重視して，次式による定式化を図った。

$$
E_{50}\left(S_{\mathrm{h}}, \sigma_{3}^{\prime}\right)=a_{1} \sigma_{3}^{\prime a_{2}} \cdot\left(1+b_{1} S_{\mathrm{h}}^{b_{2}}\right)
$$

ここで, $a_{1}, a_{2}, b_{1}, b_{2}$ は $\mathrm{MH}$ 飽和率 $S_{\mathrm{h}}$ や有効拘束圧 $\sigma_{3}{ }^{\prime}$ に依存 しない定数である。 $\mathrm{MH}$ 飽和率 $S_{\mathrm{h}}=0 \%$ のとき，(2) 式は,

$$
E_{50}\left(0, \sigma_{3}^{\prime}\right)=a_{1} \sigma_{3}^{\prime a_{2}}
$$

と書ける。Fig. 11 に, 飽和砂供試体 $\left(S_{\mathrm{h}}=0 \%\right)$ の割線変形係数 $E_{50}$ と有効拘束圧 $\sigma_{3}{ }^{\prime}$ との関係を示す。これらの関係を, 豊浦砂, 7 号珪砂, 8 号珪砂のそれぞれについて最小二乗近似すると, 次 式が得られる。

豊浦砂 $($ 太実線 $): E_{50}\left(0, \sigma_{3}{ }^{\prime}\right)=229 \sigma_{3}{ }^{10.54}$

7 号珪砂 ( 細実線 $): E_{50}\left(0, \sigma_{3}{ }^{\prime}\right)=193 \sigma_{3}{ }^{\prime 0.47}$

8 号珪砂 $($ 破線 $): E_{50}\left(0, \sigma_{3}{ }^{\prime}\right)=144 \sigma_{3}{ }^{0.36}$

（4）式，(5) 式，(6) 式の決定係数は，それぞれ，0.97，0.97，0.96
であった。(4) 式から (6) 式の右辺を見ると, 有効拘束圧に関する べき指数は, 豊浦砂, 7 号珪砂, 8 号珪砂の順に大きく, このこ とは, 飽和砂供試体の割線変形係数におよぼす有効拘束圧の影響 が, 豊浦砂, 7 号珪砂, 8 号珪砂の順に大きいことを示唆している。

$\mathrm{MH}$ 含有砂供試体 $\left(S_{\mathrm{h}}>0 \%\right)$ の割線変形係数は, 飽和砂供試体 $\left(S_{\mathrm{h}}=0 \%\right)$ のそれよりも大きい。ここで, (4) 式, (5) 式, (6) 式によ り求められる各有効拘束圧下での飽和砂供試体の割線変形係数を 基準として, $\mathrm{MH}$ 含有砂供試体の割線変形係数 $E_{50}$ を正規化した 值を, $E_{50}$ *と書くことにする。Fig. 12 に, MH 含有砂供試体の 試験結果より求めた, 正規化した割線変形係数 $E_{50}$ * と MH 飽和 率 $S_{\mathrm{h}}$ との関係を示す。図より, 正規化した割線変形係数 $E_{50} *$ に およぼす有効拘束圧の影響は小さいといえよう。（2）式の仮定に 基づけば, 正規化した割線変形係数 $E_{50}$ * は, 次式のように表さ れる。

$$
E_{50} *=\frac{E_{50}\left(S_{\mathrm{h}}, \sigma_{3}^{\prime}\right)}{E_{50}\left(0, \sigma_{3}^{\prime}\right)}=1+b_{1} S_{\mathrm{h}}^{b_{2}}
$$

(7) 式の右辺には $\sigma_{3}^{\prime}$ が含まれていない。すなわち, (2) 式は, Fig. 12 に示した結果において, 有効拘束圧 $\sigma_{3}{ }^{\prime}$ の影響を無視した仮定 といえる。砂の種類によらず Fig. 12 に示した全ての結果に対し, (7) 式の形で最小二乗近似すると, 次式が得られる。

$$
E_{50} *=1+5.7 \times 10^{-4} S_{\mathrm{h}}^{2.0} \text {. }
$$

Fig. 12 には, (8) 式による曲線も示した。

以上により, 割線変形係数 $E_{50}$ を有効拘束圧 $\sigma_{3}{ }^{\prime}$ と $\mathrm{MH}$ 飽和率 $S_{\mathrm{h}}$ の関数として (2) 式で表した場合における， $a_{1}, a_{2}, b_{1}, b_{2}$ の 

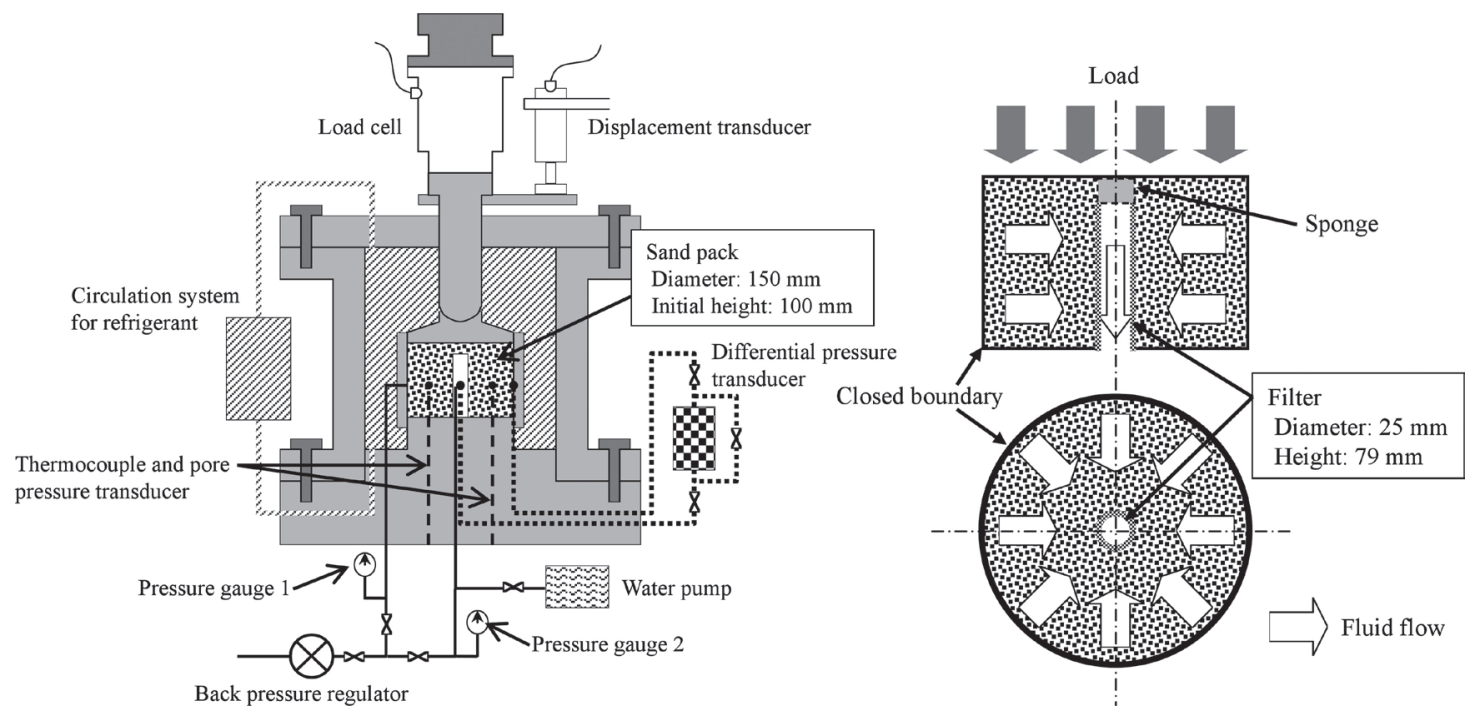

Fig.13 Schematic illustration of the apparatus for methane hydrate dissociation test.

Table 4 Conditions of methane hydrate dissociation test.

\begin{tabular}{llll}
\hline Run No. & 1 & 2 & 3 \\
\hline Sand & Toyoura sand & No.7 silica sand & No.8 silica sand \\
\hline Initial porosity, $\%$ & 38.5 & 38.1 & 39.4 \\
\hline Initial methane hydrate saturation, $\%$ & 39.3 & 40.4 & 36.0 \\
\hline Initial temperature of sample, ${ }^{\circ} \mathrm{C}$ & 11.1 & 10.7 & 10.6 \\
\hline Refrigerant temperature,${ }^{\circ} \mathrm{C}$ & 11.0 & 11.0 & 11.0 \\
\hline Outlet pressure, $\mathrm{MPa}$ & 3.10 & 3.30 & 3.17 \\
\hline
\end{tabular}

值が得られたことになる。これらの值を用いたとき，豊浦砂，7 号珪砂, 8 号珪砂を使用した MH 含有砂供試体の割線変形係数 $E_{50}$ (試験結果) に対する (2) 式の決定係数は, それぞれ $0.70,0.86$, 0.88 であった。

\section{4. 模擬 $\mathrm{MH}$ 層減圧分解試験}

\section{$4 \cdot 1$ 試験方法と試験条件}

模擬 MH 層減圧分解試験 7) では, 内径 $150 \mathrm{~mm}$, 高さ $100 \mathrm{~mm}$ のステンレス製浮動管内に砂を充填し，ガス浸透法により孔隙内 にMH を生成させたサンドパックを供試体として用いた。実験 装置の概略を Fig. 13 に示す。本装置を用いて, 供試体上端部に 一定の地盤応力 $11 \mathrm{MPa}$ に相当する荷重 $195 \mathrm{kN}$ を載荷したまま, サンドパック内を滅圧することにより, 有効応力の増加および MH の分解に伴う供試体の圧縮挙動を取得した。なお, 試験では 側面摩擦の影響を考慮していない。試験中, 浮動管およびキャッ プの外部には, 温度を $11^{\circ} \mathrm{C}(284 \mathrm{~K})$ に制御した冷媒を循環させた。 サンドパック内の間隙圧と温度は, サンドパックの中心軸からの 距離 $r=25 \mathrm{~mm}, 37.5 \mathrm{~mm}, 50 \mathrm{~mm}$ および $62.5 \mathrm{~mm}$ の箇所におい て測定した。サンドパック内の減圧は, 背圧弁を用いてサンドパッ ク中央部に設置した焼結フィルタ内の水圧を, 約 $2 \mathrm{~min}$ かけて初 期值 $10 \mathrm{MPa}$ から所定の $\mathrm{MH}$ 分解圧力 $3 \mathrm{MPa}$ まで減圧することに より行った。なお, 分解試験中, 供試体上端部に載荷する荷重は 初期值 $195 \mathrm{kN}$ のまま一定に保った。本報で数值シミュレーショ ンの対象とした模擬 MH 層減圧分解試験の試験条件を Table 4 に示す。Run No.1, Run No.2, Run No.3 は, それぞれ, 豊浦砂, 7 号珪砂， 8 号珪砂を用いてサンドパックを作製したものである。 その他の試験方法および試験条件に関する詳細は既報 7) を参照 されたい。Fig. 14 には, 分解試験中におけるサンドパック内の
圧力変化を示した。Fig. 14 (a), (b), (c) の図に は, Fig. 13 に示した Pressure gauge 1 と Pressure gauge 2 による 2 つの測定值をそれぞれ示した が，いずれの試験でも，両者はほぼ重なってい る。このことから, 減圧時および MH の分解中, サンドパック内の排水，すなわち圧力伝播は, 十分速やかに行われたものと考えられ, サンド パック内の任意の点における間隙圧の経時変化 は等しかったものと考えられる。

模擬 $\mathrm{MH}$ 層減圧分解試験におけるサンドパック内の温度変化 をFig. 15 に示す。Fig. 15 (a)，(b)，(c) は，それぞれ Run No.1， Run No.2, Run No.3の結果を示している。温度の計測箇所は, サンドパックの中心軸から距離 $r=25 \mathrm{~mm}, 37.5 \mathrm{~mm}, 50 \mathrm{~mm}$ お よび $62.5 \mathrm{~mm}$ 離れており, それぞれの計測箇所における温度を Temp.1，Temp.2，Temp.3および Temp.4 として表記した。減圧開 始直後, MH の分解に伴う吸熱反応により, サンドパック内の温. 度は急激に降下し, MH の分解圧力 $3 \mathrm{MPa}$ に対応する平衡条件 2 ${ }^{\circ} \mathrm{C}(275 \mathrm{~K})$ 付近に達する。その後, $\mathrm{MH}$ の分解中, 各計測箇所の 温度はほぼ一定に保たれる。各計測箇所の近傍において MH の 分解が終了すると, 外部からの熱伝導により温度は上昇しはじめ, 最終的には浮動管およびキャップの外側を循環する冷媒温度 11 ${ }^{\circ} \mathrm{C}$ に近づいていく。外壁面に近い計測箇所ほど，すなわち，サン ドパックの中心軸から遠い計測箇所ほど, 熱が多く供給されるた め, 早期に MH の分解が終了し, 温度上昇が観察される傾向が 見られる。Fig. 15 (a) から (c)の間には顕著な違いは見られなかっ た。既に述べたように, サンドパック内の圧力伝播は十分速やか であったことから, 本報の模擬 MH 層減圧分解試験の場合には, 細粒砂が MH の分解挙動に対してほとんど影響をおよぼさなかっ たものと考えられる。ただし, 細粒砂をより多く含有する砂の場 合には, 細粒砂が MH 層の浸透率に影響をおよぼし, 間接的に MH の分解挙動に影響をおよぼすと予測される。さらに, スケー ルが大きくなるほど，その影響は大きくなるものと考えられる。

模擬 $\mathrm{MH}$ 層減圧分解試験におけるサンドパックの圧縮量変化を Fig. 16 に示す。減圧開始直後, 有効応力の増加によって, サンド パックは急激に圧縮される。その後, MH の分解が進行するのに 伴って, サンドパックは徐々に圧縮していく。最終的な圧縮量は, 豊浦砂, 7 号珪砂, 8 号珪砂の順に小さく, 上述した三軸圧縮試 

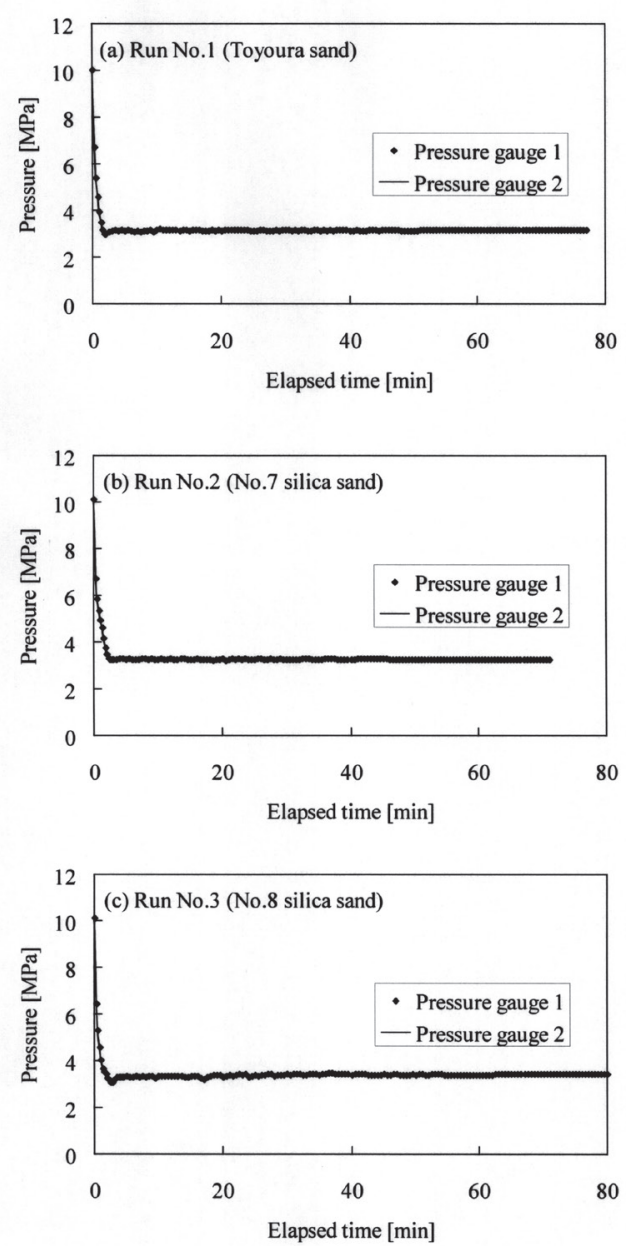

Fig.14 Measured pressure during methane hydrate dissociation in the sand pack containing (a) Toyoura sand (Run No.1), (b) No.7 silica sand (Run No.2) and (c) No.8 silica sand (Run No.3).

験において, 割線変形係数の高い順と一致する。MH の分解過程 におけるサンドパックの圧縮量の経時変化は, MH の分解挙動と サンドパックの力学特性に依存するが，既に述べたように，本報 の模擬 MH 層減圧分解試験の場合には, 細粒砂が MH の分解挙動 に対しては，ほとんど影響をおよぼさなかったものと考えられる。 従って, Fig. 16 に示した砂による圧縮量変化の違いは, 主にサン ドパックの力学特性の違いに起因するものと考えられる。

\section{$4 \cdot 2$ 計算条件}

坂本ら ${ }^{21)}$ は, 模擬 MH 層減圧分解試験 7) の数值シミュレーショ ンにより, 試験において観察された MH の分解挙動, 模擬 MH 層の変形挙動, ガスー水産出挙動の再現を図った。しかし, 坂本 $5^{21)}$ は, 模擬 $\mathrm{MH}$ 層の変形挙動を評価する上で重要な変形係数 として, 豊浦砂を用いた MH 含有砂の三軸圧縮試験結果のみを 基に導出したものを適用していた。そのため, 例えば, 8 号珪砂 を用いてサンドパックを作製した試験における圧縮量変化を再現 するためには, MH 層のポアソン比としてかなり低い值を設定し なくてはならなかったとの見解を示した。本報では, 上述した豊 浦砂， 7 号珪砂，8 号珪砂を用いて作製した飽和砂供試体および MH 含有砂供試体の三軸圧縮試験結果を用いて, それぞれの砂を 用いた模擬 MH 層減圧分解試験の数值シミュレーションを実施 し，Fig. 16 に示したサンドパックの圧縮量変化の再現を試みる。 数值シミュレーションは, メタンハイドレート資源開発研究
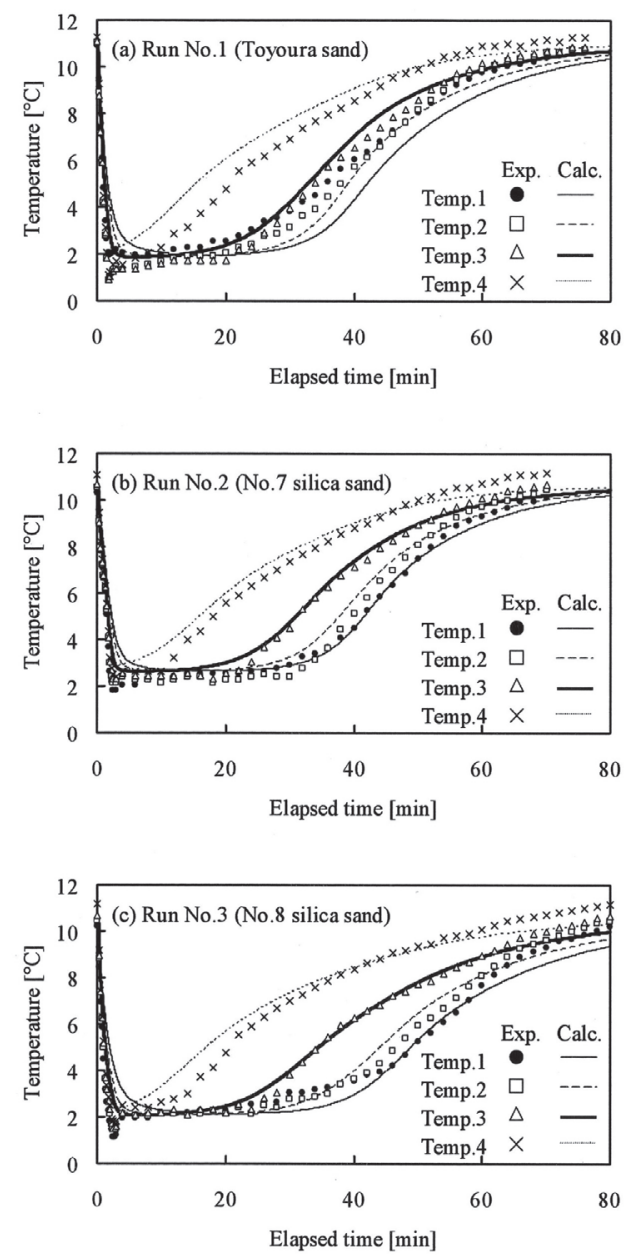

Fig.15 Experimental and calculated results for the change in temperatures in the sand pack containing (a) Toyoura sand (Run No.1), (b) No.7 silica sand (Run No.2) and (c) No.8 silica sand (Run No.3) .

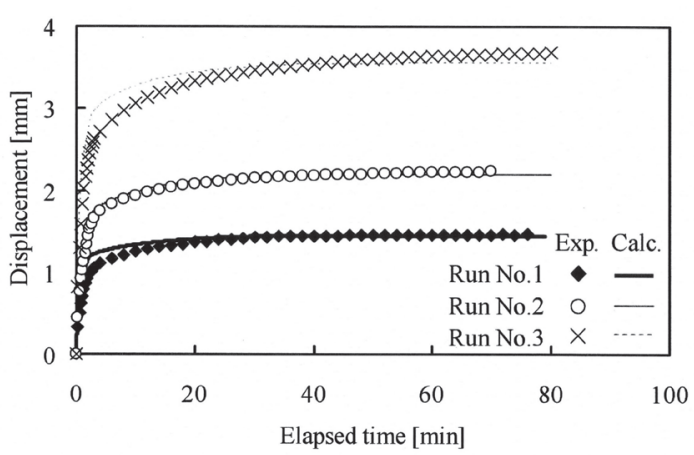

Fig.16 Experimental and calculated results for the change in displacement of the sand pack containing (a) Toyoura sand (Run No.1), (b) No.7 silica sand (Run No.2) and (c) No.8 silica sand (Run No.3) .

コンソーシアムのもと開発された数值シミュレータ COTHMA (Coupled thermo-hydro-mechanical analysis with dissociation and formation of methane hydrate in deformation of multiphase porous media）を用いて行った。本プログラムは, 固一液一気の三相で構 成される多孔質体における応力一浸透流一熱移動を完全連成した 有限要素法解析ツールである。

数值シミュレーションでは 2 次元円筒座標系モデルを用いた。 


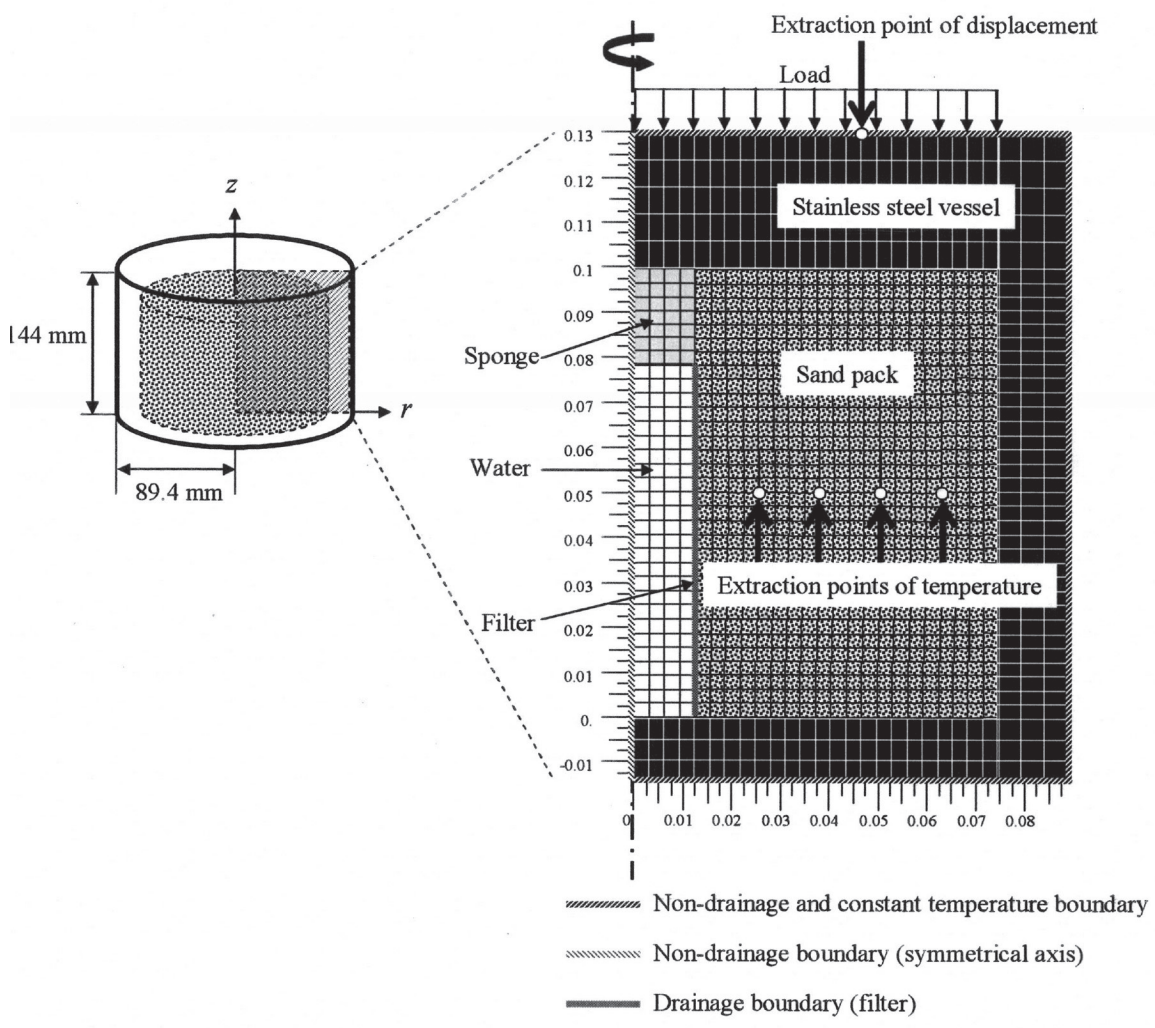

Fig.17 Grid system and boundary conditions for numerical simulation of methane hydrate dissociation test.

Fig. 17 に実験装置を模擬した解析領域および境界条件の概略を 示す。解析領域の大きさは, $r$ 方向 $89.4 \mathrm{~mm}, z$ 方向 $144 \mathrm{~mm}$ である。 サンドパックに相当する部分のメッシュ幅は, $r$ 方向 $3.125 \mathrm{~mm}$, $z$ 方向 $3.16 \mathrm{~mm}$ である。サンドパックとサンドパック中央部の焼 結フィルタの間に設けた接触面要素に対しては, 実験における出 口圧力の時間変化を圧力の境界条件として与えた。容器のステン レス部分の浸透率として, 極端に小さい值 $\left(1.00 \times 10^{-25} \mathrm{~m}^{2}\right)$ を設 定し，流体の流動に関しては実質的に閉境界の取り扱いとした。 実験において, 容器外部の温度は冷媒循環装置により一定に保た れるため, 容器の外壁面温度を一定とする境界条件を与えた。

数值シミュレーションの手順および数值モデルの詳細は既報 ${ }^{21)}$ を参照されたい。

\section{$4 \cdot 3$ 数值シミュレーション結果}

Fig. 15 には, 模擬 MH 層減圧分解試験におけるサンドパック 内の温度変化の数值シミュレーション結果も示した。数值シミュ レーションでは, MH 含有砂の見かけの熱伝導率を, 分散モデ ル21-23)により算出した。数值シミュレーション結果は, 減圧に よる $\mathrm{MH}$ の分解やガス, および, 水の流動に伴って間隙中の水, メタン, MH の飽和条件が時間とともに変化する過程において, 試験により得られた温度変化に関する挙動を, 概ね再現している。 このことは, 既報 ${ }^{21)}$ で述べたとおり, 数值シミュレーションに より, サンドパック内の MH の分解挙動を良好に再現できてい ることを意味している。

Fig. 16 には, 模擬 MH 層減圧分解試験におけるサンドパック の圧縮量変化の数值シミュレーション結果も示した。MH 含有砂 は弾性的に振る舞うと仮定し, 見かけの弾性係数として三軸圧 縮試験より得られた (2) 式を用いた。豊浦砂，7号珪砂，8号珪 砂から成る $\mathrm{MH}$ 含有砂の見かけのポアソン比を, それぞれ 0.32 ,
0.26, 0.23 と仮定した場合, Fig. 16 に示寸ように, 模擬 MH 層減 圧分解試験で得られたサンドパックの圧縮量変化を良好に再現す ることができた。既報 ${ }^{21}$ )では, 特に 8 号珪砂 (Run No.3) の場合 に, 見かけのポアソン比として, 地盤材料としてはかなり低い值 (0.07) を与えなければ, 模擬 MH 層減圧分解試験の結果を再現で きなかったとした。本報で用いた見かけのポアソン比は, 地盤材 料のポアソン比として, 妥当な範囲にあるといえ, この観点か らすると，(4) 式から（6) 式のように, 使用した砂によって (2) 式 における $a_{1}, a_{2}$ の值を個別に設定したことは有意義であったと いえよう。ただし，本報で用いた見かけのポアソン比は，Fig. 8 やFig. 9 に示した割線ポアソン比の值よりもやや大きい。本報で は, 簡単のため, 強度の $50 \%$ の点における割線変形係数を数值 シミュレーションに用いた。Fig. 4 に見られるように, 応力ーひ ずみ曲線の接線の傾きはひずみに依存して変化しており, 例えば Duncan-Chang モデルなどによって, この挙動を考慮した定式化 を行い, 数值シミュレータに導入して, 再検討する必要があると 考える。さらに, 特にフィールドスケールのシミュレーションを 考慮した場合には, 塑性挙動や粘性挙動を表現する構成方程式の 構築も必要不可欠と考える。これらの点に関しては今後の課題で ある。

\section{5. まとめと今後の課題}

本報では, 細粒分を含む MH 含有砂供試体の三軸圧縮試験を 行い, 細粒分を含まない豊浦砂を用いた既報 ${ }^{18)}$ の結果との比較 を通じて, MH 含有砂供試体の力学特性におよぼす細粒分の影響 を調べた。本報の主な成果を以下に示す。

(1) 粒径分布の範囲が広い砂により骨格が形成された供試体で は, それが狭い砂により骨格が形成された供試体よりも載荷方向 
への変形が大きく, 載荷方向と垂直な方向への変形は相対的に小 さい傾向がある。これは, 細粒分などの相対的に小さな粒子が, 骨格の隙間へ貫入しやすいためと考えられる。

（2）豊浦砂を用いて作製した MH 含有砂供試体の場合と同様, MH 飽和率が大きいほど，また，有効拘束圧が大きいほど，細粒 分を含む MH 含有砂供試体の強度や載荷初期の応力ーひずみ曲 線の傾きは大きい。

（3）豊浦砂を用いて作製した MH 含有砂供試体の三軸圧縮特性と 比較したところ，強度に関しては，細粒分の影響はほとんど見ら れないが, 載荷初期における応力ーひずみ曲線の傾きに関しては, 細粒分を多く含む供試体ほど小さい。

（4）豊浦砂を用いて作製した MH 含有砂供試体の場合と同様，有 効拘束圧が大きいほど, 細粒分を含む $\mathrm{MH}$ 含有砂供試体の割線 ポアソン比は低下する傾向がある。また, 細粒分が割線ポアソン 比におよぼす影響は見られなかった。

(5) 天然 MH 層コアサンプルの強度は, 豊浦砂， 7 号珪砂，8 号 珪砂を用いて作製した MH含有砂供試体と同程度であった。また, 割線変形係数については, 細粒分を含む 7 号珪砂や 8 号珪砂を用 いて作製した MH 含有砂供試体に近い。

(6) 三軸圧縮試験結果の一部を定式化して, 数值シミュレータ (COTHMA) に組み込み, 模擬 MH 層減圧分解試験の数值シミュ レーションを行った。模擬 MH 層減圧分解試験における, 減圧 およびMHの分解に伴うサンドパックの圧縮量変化は, 数值シ ミュレーションにより良好に再現できた。しかし,数值シミュレー ションに用いたポアソン比は, 三軸圧縮試験より得られた割線ポ アソン比よりもやや大きかった。

$\mathrm{MH}$ 含有砂の力学特性に関して, 不明な点は多く残されている。 例えば, 本報では, 室内スケールでの試験と数值シミュレーショ ンを行ったが，広域かつ長期的な MH の生産を考えた場合には， MH 層の時間依存性挙動に関する知見が必要不可欠である。しか し, これに関して得られている情報はまだ不十分である。また, 本報では, MH 含有砂の力学挙動を表す構成方程式として, 有効 拘束圧依存性および MH 飽和率依存性を考慮した弾性モデルを 用いたが，構成方程式を改良する余地は大いにある。 $\mathrm{MH}$ 層の力 学挙動をより高精度で解析するためには, 構成方程式の改良が重 要な課題のひとつといえよう。

謝辞本研究は, 経済産業省メタン八イドレート開発促進事 業に係る生産手法開発に関する研究の一部として実施したもので ある。ここに付記して, メタンハイドレート開発研究コンソーシ アムに謝意を表する。
独立行政法人産業技術総合研究所メタンハイドレート研究セン ター 栘井明氏ならびに大野孝雄 氏，株式会社日本アクシス 永 瀬茂紀 氏には，室内試験の実施やデータの提供，供試体の作製， 試験結果の考察などの面で多大なるご協力をいただいた。ここに 感謝の意を表する。

西日本技術株式会社 森二郎氏，方火浪氏には，COTHMAの 開発および数值シミュレーションの実施の面で多大なるご協力を いただいた。ここに感謝の意を表する。

\section{References}

1) Y. Okuda: Petrotech, 16 (1993), 300-306.

2) M. Sato and Y. Aoki: J. Jpn. Inst. Energy, 80 (2001), 973-995

3) M. Sato: J. Jpn. Inst. Energy, 80 (2001), 1064-1074

4) MH21 Research Consortium: http://www.mh21japan.gr.jp/japanese/index.html

5) T. Fujii, T. Saeki, T. Kobayashi, T. Inamori, M. Hayashi, O. Takano, T. Takayama, T. Kawasaki, S. Nagakubo, M. Nakamizu and K. Yokoi: Offshore Technology Conf., (Houston, 2008), OTC 19310

6) Y. Sakamoto, M. Shimokawara, K. Ohga, K. Miyazaki, T. Komai, K. Aoki and T. Yamaguchi: Journal of MMIJ, 124 (2008), 20-29.

7) Y. Sakamoto, M. Shimokawara, K. Ohga, K. Miyazaki, T. Komai, K. Aoki and T. Yamaguchi: Journal of MMIJ, 124 (2008), 498-507.

8) W. J. Winters, I. A. Pecher, J. S. Booth, D. H. Mason, M. K. Relle and W. P. Dillon: Geological Survey of Canada, Bulletin 544 (1999), pp.241-250.

9) W. J. Winters, W. F. Waite, D. H. Mason, P. Kumar: Proc. of the 6th Int. Conf. on Gas Hydrates, (Vancouver, 2008), CD-ROM.

10) M. Hyodo, Y. Nakata, N. Yoshimoto and T. Ebinuma: Soils and Foundations, 45 (2005), 75-85.

11) A. Masui, H. Haneda, Y. Ogata and K. Aoki: Proc. of the 15th Int. Offshore and Polar Eng. Conf., (Seoul, 2005), pp.364-369.

12) A Masui, H. Haneda, Y. Ogata and K. Aoki: Proc. of the 7th ISOPE Ocean Mining Symposium, (Lisbon, 2007), pp.53-56.

13) J. Yoneda, M. Hyodo, Y. Nakata, N. Yoshimoto and T. Ebinuma: Ground Engineering, 25 (2007), 113-122.

14) K. Miyazaki, A. Masui, Y. Sakamoto, H. Haneda, Y. Ogata, K. Aoki, T. Yamaguchi and S. Okubo: Journal of MMIJ, 123 (2007), 537-544.

15) K. Miyazaki, A. Masui, Y. Sakamoto, H. Haneda, Y. Ogata, K. Aoki, T. Yamaguchi and S, Okubo: Journal of MMIJ, 124 (2008), 619-625.

16) A. Masui, K. Miyazaki, H. Haneda, Y. Ogata and K. Aoki: Proc. of the 6th Int. Conf. on Gas Hydrates, (Vancouver, 2008), CD-ROM.

17) K. Miyazaki, T. Yamaguchi, Y. Sakamoto, H. Haneda, Y. Ogata, K. Aoki and S. Okubo: Journal of MMIJ, 125 (2009), 156-164.

18) K. Miyazaki, T. Yamaguchi, Y. Sakamoto, N. Tenma, Y. Ogata and K. Aoki: Journal of MMIJ, 126 (2010) , 408-417

19) T. Fujii, T. Namikawa, M. Nakamizu, Y. Tsuji, T. Okui, M. Kawasaki and K. Ochiai: Proc. of the 5th Int. Conf. on Gas Hydrates, (Trondheim, 2005), pp.974-979.

20) Y. Sakamoto, M. Kakumoto, K. Miyazaki, N. Tenma, T. Komai, T. Yamaguchi, M. Shimokawara and K. Ohga: Int. Journal of Offshore and Polar Engineering, 19 (2009), 124-134.

21) Y. Sakamoto, M. Kakumoto, K. Miyazaki, N. Tenma, T. Komai, K. Aoki and T. Yamaguchi: Journal of MMIJ, 126 (2010), 631-639.

22) Y. Yamamoto, T Kawamura, M. Ohtake, T. Komai, F. Nakagawa, T. Tsuji and Y. Tsukada: Proc. of the 14th Int. Offshore and Polar Eng. Conf., (Toulon, 2004), pp 36-40.

23) Y. Yamamoto, T. Kawamura, M. Ohtake, T. Komai, F. Nakagawa, T. Tsuji and Y. Tsukada: Proc. of the 15th Int. Offshore and Polar Eng. Conf., (Seoul, 2005), pp. 341-345. 